\title{
TREND LESZ-E (A JÖVŐBEN IS) A BÜNÖZÉS CSÖKKENÉSE?
}

\section{WILL THE TREND OF CRIME DECLINE CONTINUE IN THE FUTURE TOO?}

\author{
Kerezsi Klára \\ az MTA doktora, egyetemi tanár, a Rendészettudományi Doktori Iskola vezetője, Országos Kriminológiai Intézet, Budapest \\ Nemzeti Közszolgálati Egyetem Rendészettudományi Kar, Budapest \\ kerezsi@okri.hu
}

\section{ÖSSZEFOGLALÁS}

\begin{abstract}
A tanulmány a magyar bűnözési helyzetet vizsgálja elsősorban a rendőrség által nyilvántartott bűncselekmények hivatalos adatai alapján. Magyarországon 2000 óta jelentősen csökken a bünözés, mind a vagyon elleni, mind az erőszakos bűncselekmények körében. A bűnözés csökkenése számos más fejlett ipari országban is tapasztalható. Mit tudunk ezekről a változásokról? Mi hozta őket? Annak ellenére, hogy több mint egy évtizede csökken a bűnözés, a hazai kriminálpolitika továbbra is a bűnözés növekedésének feltételezésére épül. Hasznos és megbízható információk nélkül az országos és helyi politikai döntéshozók iránytű nélkül lehetnek a szakpolitikai beavatkozások megfogalmazása és értékelése során. Ez a cikk a bűnözés csökkenésének főbb jellemzőit vizsgálja, de szélesebb körű áttekintést is nyújt a bűncselekmények globális viszszaesésének értékelésére. A szerző a bűnözési tendenciákkal foglalkozó szakirodalom elemzése alapján többféle magyarázatot is kínál a bűnözés visszaesésére.
\end{abstract}

\section{ABSTRACT}

This article presents crime statistics in Hungary based on official figures for police-recorded offences. Crime in Hungary has been decreasing significantly since 2000, in terms of both property crime and violent crime. This observed decrease in crime also been seen in a large number of other industrialized countries. What is known about these changes? What brought them about? After declining or remaining stable for more than a decade, the Hungarian criminal policy continues to be based on the concept of increasing crime. Without useful and reliable information, national and local policymakers fly blind when formulating and evaluating the effectiveness of policy interventions. This paper examines the key features of the crime decline in Hungary but also takes a broader look at it globally. An analysis of research literature on crime trends has identified several different explanations for the crime drop.

Kulcsszavak: bűnözési trendek, erőszakos bűnözés, bűnözéscsökkenés, bűnözési magyarázatok, biztonságiasítás

Keywords: crime trends, violent crime, crime decline, crime explanations, securitisation 


\section{BEVEZETÉS}

Minden külön értesítés helyett: a bünözés csökken. Nemcsak Magyarországon, de Európában, az USA-ban és szerte a világon is. Írásomban az elmúlt két évtized bünözésének alakulását követem nyomon, és a nemzetközi adatok, tendenciák, továbbá a szakirodalom segítségével megkísérlek választ adni a bünözés csökkenésének hazai és nemzetközi okaira.

A szenzációhajhász médiabeszámolók és hírek alapján ugyanis könnyen lehet az a benyomásunk, hogy a bünözés átható és jelentős növekedésben van. Keleti és nyugati kutatások is azt mutatják, hogy az emberek jelentősen túlértékelik a bünözési veszélyt, és sokkal jobban félnek, mint amennyire kellene. Vizsgáljuk meg tehát azt az új helyzetet, amikor a bünözés csökken. A kedvező trendek milyen hatást gyakorolnak az országok kriminálpolitikájára, a büntető igazságszolgáltatási rendszerek müködésére, a börtönnépesség alakulására, és nem utolsósorban, milyen hatással vannak a lakosság biztonságérzetére.

\section{A BÜNÖZÉS CSÖKKENÉSE AZ AMERIKAI KONTINENSEN KEZDŐDÖTT}

A bűnözéssel kapcsolatosan a leghosszabb időtartamot átfogó adatszerzési forrás az ENSZ Bünözési kutatása. A felméréseket az 1970-es években kezdték, és a legutóbbi felmérésben 82 ország vett részt. Az adatbázis 518 változóból áll. 1980 és 2000 között a regisztrált büncselekmények száma növekedést mutatott (1980: 2300 bcs/100e lakos; 2000: 3000 bcs/100e lakos). Különösen Latin-Amerikában emelkedett a bünözés, és - kisebb mértékben ugyan, de - Kelet-Közép-Európa is növekvő bünözéssel szembesült.

Az 1990-es években azonban változások kezdődtek. Először Észak-Amerikában, ahol a százezer lakosra számított bünözési gyakoriság jelentösen csökkent. A kedvező változásokat a lakossági megkérdezésekkel végzett Nemzetközi Viktimológiai Vizsgálat adatai is megerősítették (Kesteren et al., 2013).

Az Egyesült Államokban az 1990-es évek elején százezer lakosra 750 erőszakos bủncselekmény esett. A mutató 2013-ra több mint 50\%-kal csökkent, és százezer lakosra már csak 368 erőszakos büncselekmény jutott. 1980 és 2014 között 39\%-kal csökkent az erőszakos bünözési ráta, és 1993-2016 között az áldozattá válás gyakorisága is $20 \%$-os csökkenést mutatott, az időszakon belül is kiemelkedő mértékben, 40\%-kal csökkent az 1995 és 2010 közötti években (Tcherni-Buzzeo, 2018). A nagyvárosok tapasztalták az intenzívebb csökkenést, de minden város, kisváros és település is megtapasztalta a bünözés áldásos változását. Andrew V. Papachristos és munkatársai azt vizsgálták, hogy vajon minden városi szomszédságot érint-e az erőszakos bünözés csökkenése. A Chicago 
városában lefolytatott kutatás azt találta, hogy - bár abszolút értelemben szinte minden szomszédság profitált a bünözés csökkenéséből - a bünözésben a város legbiztonságosabb és legveszélyesebb területei közötti relatív egyenlőtlenség 10\%-kal növekedett. Ez a növekedés abból eredt, hogy a leginkább biztonságos területeken jóval nagyobb mértékủ volt a bünözés csökkenése. Az adatok azonban azt is jelezték, hogy a legsúlyosabb büncselekmények, mint például az emberölés, továbbra is gyakrabban fordultak elö a hátrányos helyzetü szegregátumokban, azaz a csökkenés nem írta felül a korábbi területi egyenlőtlenségeket (Papachristos et al., 2018).

Az USA-ban a nagymérvü bevándorlás korábban is a migránsokra vonatkozó sztereotípiákkal kapcsolódott össze. Száz évvel ezelőtt bizottságok vizsgálták a bevándorlás hatásait és kapcsolatát a bünözéssel, napjainkban hasonló félelmek fogalmazódnak meg, most a dokumentumok nélkül érkező dél-amerikaiakkal kapcsolatosan. Bár már évek óta visszhangozza ezeket az aggodalmakat a média, az adatok szerint ugyanezen időszak alatt az erőszakos és a vagyon elleni bünözés a felére csökkent, és a csökkenés pont azokban a nagyvárosokban tapasztalható nagyobb mértékben, amelyek a bevándorló népesség célterületei. Az elmúlt huszonöt évben meredeken, kb. 60\%-kal csökkent a latin ajkú népességben az emberölési ráta. Ráadásul mindez párhuzamosan zajlott az igen erőteljes migrációs népességszám növekedéssel. Ramiro Martinez és munkatársai kutatása, az egyik jelentősebb kubai emigrációs hullám után, az etnikai jellegű emberölések gyakoriságát hasonlította össze 1980 és 2000 között Miamiban és San Diegóban. Mindkét város a migráció kiemelt célterülete. A tapasztalatok szerint az újonnan érkező bevándorlók rosszabbul képzettek voltak, mint a korábban Kubából érkező migránsok. Kulturálisan is különböztek, lévén kivándorlásuk előtt a kommunista időszakban nevelkedtek Kubában. Az új bevándorlók megérkezése intenzív állampolgári aggodalmakat váltott ki a bevándorlási körzetekben, a bünözés is növekedett, bár a kutatás szerint a két jelenség között nem volt tudományosan is bizonyítható összefüggés (Martinez et al., 2015).

\section{A CSÖKKENÉS \\ A FEJLETT ORSZÁGOKBAN FOLYTATÓDOTT}

A századfordulóig az Európai Unió országai kevésbé tiszta képletet jeleztek: az 1980-as évek kezdetén tapasztalt növekedés után, csak az 1990-es évekre stabilizálódott a bünözés. Az EU-ban - időnkénti emelkedésekkel - hektikusan stagnált a bünözés.

A kedvező fordulat a 21. század elején következett be, amikor a stagnálást határozott csökkenés váltotta fel. Hollandiában például az 1980-1990 közötti emelke- 
dő trend 2002-ben megfordult, és az elmúlt másfél évtizedben 30\%-os bünözési csökkenést regisztráltak. Igaz viszont az is, hogy a jelentősen csökkenő trend mellett néhány büncselekményi kategória átmenetileg mérsékelten növekedett, mint például a lakásbetörés vagy a rablás. A bünözés 2012 óta tartó csökkenése azonban megerősítette a lakosság biztonságérzetét. Hollandiában a fiatalkorú bünelkövetők száma 2007 óta csaknem 50\%-kal csökkent, úgy a fiúknál, mint a lányoknál, mi több, az etnikai kisebbségi és a bennszülött hollandoknál egyaránt érzékelhető volt (de Waard, 2015).

A rendőrség által regisztrált adatok növekedést mutattak a droggal kapcsolatos és egyes erőszakos cselekményekben, a vagyon elleni cselekmények azonban 1990 körül tetőztek, ezután csökkenni kezdtek. A vagyon elleni büncselekmények felfutása összefüggött az 1990-es évek keleti határnyitása következtében kialakult új feketepiacokkal, míg az értékesítési lehetőségek kimerülése, és a határrendészet felkészültségének megerősödése, illetve a nyugat-európai háztartásokban a biztonságtechnikai eszközök elterjedése visszaszorították a vagyon elleni bünözést. Ezt jelzik az Eurostat adatai is: 2008 és 2016 között a lakásbetörések száma 10\%-kal, a gépjármúlopások száma 36\%-kal csökkent. A rablás 2016-ban 24\%-kal volt kevesebb, mint 2012-ben.

Úgy tűnik, hogy az erőszakos és a vagyon elleni bűnözés eltérő trendet követ Nyugat-Európában: a tradicionális vagyon elleni bünözés és az emberölés az 1990-es évek vége óta csökken, a más típusú eröszakos cselekmények, és a droggal kapcsolatos cselekmények pedig növekszenek ugyanezen időszak alatt (Aebi-Linde, 2010). Mivel a vagyon elleni bünözésre egyre inkább az online elkövetési formák jellemzők - a hagyományos (utcai) vagyon elleni cselekmények nem tükrözik megfelelően a vagyon elleni bünözés gyakoriságát.

A csökkenő trend az emberölések számában is látható. A népességszámhoz viszonyítva Lettországban és Litvániában követték el a legtöbb szándékos emberölést (2016-ban 100000 lakosra körülbelül öt emberölés jutott), tizenhárom másik EU-s tagállamban ugyanez a szám egynél kisebb volt. Összehasonlításképpen, az Egyesült Államokban 2016-ban 100000 lakosra vetítve 5,4 emberölést követtek el, míg Oroszországban 10,8-at.

Az EU országaiban 2015 és 2016 között 3\%-kal növekedett a testi sértések száma. Ez a büncselekmény még a népességnagysághoz viszonyítva is jelentős eltéréseket mutat a tagállamok között. Az eltérések nemcsak az elkövetett büncselekmények relatív gyakoriságát tükrözik, hanem a jogszabályi különbségeket és az eltérő nyilvántartási gyakorlatokat is. A rendőrség által nyilvántartásba vett erőszakos szexuális bűncselekmények száma pedig több mint 8\%-kal nőtt 2015 és 2016 között. Ide tartozik az erőszakos közösülés és egyéb szexuális támadás, jóllehet egyes országok adatai egyes büncselekménytípusokat nem feltétlenül tartalmaznak. 


\section{MIÓTA CSÖKKEN A BÜNÖZÉS MAGYARORSZÁGON?}

A rendőrség által regisztrált, és a Legfőbb Ügyészség által kiadott kriminálstatisztikai adatokat $\left(\mathrm{ENyÜBS}^{1,2}\right.$ ) vettük kiindulópontnak. A Központi Statisztikai Hivatalnál (KSH) elérhető adatbázisok is segítettek, és felhasználtuk a legfőbb ügyész éves parlamenti beszámolóit. Áttekintettünk néhány - a bünözés és a biztonság hiányának problémakörével foglalkozó - kutatás eredményeit, például: az Országos Kriminológiai Intézet (OKRI) Áldozatok és vélemények címü kutatását (Irk, 2004); illetve a Nemzeti Közszolgálati Egyetem Jó Állam Jelentését (Kaiser, 2015).

Magyarország bünözése a 100000 lakosra jutó büncselekmények számát tekintve az európai középmezőnyben található (2003: 4075; 2014: 3337). A hazai kriminálstatisztika számai is mérséklődtek, és a következő évekre további csökkenő bünözési trend valószínüsíthető (Kerezsi-Pap, 2017). A bünözési statisztikára mint hivatkozási alapra azonban csak sok-sok finomítással támaszkodhatunk. Figyelembe kell ugyanis venni, hogy a kriminálstatisztikában nem találjuk meg a látenciában maradt cselekményeket (például: a családi vagy a gyermekek elleni erőszak cselekményeit, a kisebbségi csoportok elleni erőszakos cselekményeket, vagy a korrupciós büncselekményeket). Nem jelennek meg a bünügyi statisztikáinkban a kriminális szabálysértések sem. Összességében nagy hiányossága a hazai bünözéselemzésnek és prognóziskészítésnek, hogy a devianciákat jelző statisztikák nincsenek összevetve különféle társadalomstatisztikai adatokkal. Pedig ideje lenne ezeket a kutatásokat elvégezni!

A korábbi hazai innovatív kutatási kezdeményezések közül érdemes megemlíteni Pusztai Lászlót, aki a magyar szakirodalomban elsőként vetette fel azt a kérdést, hogy vajon vannak-e a hazai bünözés változásában bünözési ciklusok. Pusztai azt figyelte meg, hogy a gazdasági fejlődés következtében fellépő válságok jellemzője az egész világra kiható globalitás, és a következmények nem maradnak a gazdaság keretei között, hanem kihatnak az egész társadalom életére, így hatása megjelenik a bünözésben is (Pusztai, 1987).

\section{A VÁLTOZÓ HAZAI BÜNÖZÉS: ADATOK}

2007 és 2018 között az ismertté vált közvádas büncselekmények száma, hasonlóan az ismertté vált bünelkövetők számához, folyamatosan csökkent.

${ }^{1}$ ENyÜBS - Egységes Nyomozóhatósági és Ügyészségi Bünügyi Statisztika.

2 A Büntető Törvénykönyvröl szóló 2012. évi C. törvény (az „új Btk.”) 2013. július 1-jei hatályba lépése az ENyÜBS módszertanát, tartalmát és adatgyűjtési rendszerét is átalakította. 2013-tól a hivatalos kriminálstatisztikai adatközlésben az új Btk. fejezetei és tényállásai képezik a büncselekmények csoportosításának alapját, és ezekhez igazították a visszatekintő adatokat is. 


\begin{tabular}{|l|c|c|}
\hline & Ismertté vált büncselekmények száma & Ismertté vált bünelkövetők száma \\
\hline 2007 & 426914 & 138763 \\
\hline 2010 & 447186 & 129945 \\
\hline 2011 & 451371 & 129945 \\
\hline 2012 & 472236 & 120529 \\
\hline 2013 & 377829 & 109876 \\
\hline 2014 & 329575 & 108466 \\
\hline 2015 & 280113 & 99018 \\
\hline 2016 & 290779 & 98136 \\
\hline 2017 & 226452 & 90369 \\
\hline 2018 & 199830 & 51896 \\
\hline
\end{tabular}

Az összbünözés terjedelmét jellemzően a vagyon elleni büncselekmények határozzák meg. Az e kategóriába tartozó cselekmények 1991-ig határozottan növekedtek, és ekkor az összes regisztrált büncselekmény 81\%-át tették ki. Az ezt követő időszakban ún. „hullámzó csökkenés” indult meg. A már a kétezres években is lefelé irányuló trendet még határozottabb csökkenés váltotta fel a 2010-es évek közepétől kezdődően. 2012-re az összbünözés terjedelmét döntően meghatározó büncselekménycsoport már csak az összes büncselekmény 55\%-át tette ki.

A regisztrált büncselekmények számának drasztikus visszaesésében - a Btk. változásain kívül - a szabálysértésekről szóló törvény értékhatárra vonatkozó változásai is szerepet játszhattak (az értékhatár húszezerről ötvenezer forintra emelkedett).

A fenti változások miatt az elmúlt húsz évben lassan átrendeződött a vagyon elleni és a személy elleni büncselekmények megoszlása. A személy elleni büncselekmények az összes regisztrált büncselekmény egyre nagyobb részét képezik. 2007-ben a személy elleni büncselekmények a hazai bünözés 4\%-át tették ki, 2011-ben pedig 6,2\%-át. A kategória legsúlyosabb büncselekménye az emberölés. Tény, hogy az emberölések száma 1991-1998 között megugrott, átlagosan 296-ra, ezután viszont csökkenni kezdett, s e tendencia azóta is tart (2006: 174; 2007: 154; 2008: 147; 2009: 139; 2010: 135; 2011: 156; 2012: 113). A vizsgált időszak elején a testi sértések száma emelkedett (2007: 6796; 2008: 7631), majd a nyugat-európai trendekhez hasonlóan a csökkenés - némi időeltolódással - ebben a kategóriában is bekövetkezett (2010: 7832; 2011: 6791; 2012: 6583). ${ }^{3}$

\footnotetext{
${ }^{3}$ Frissebb adattal a Btk. módosítása és a statisztikai rendszer megváltozása miatt nem lehet szolgálni. Lásd: Tájékoztató a bünözésről. Évenként kiadja a Legfőbb Ügyészség, Budapest.
} 
A nemi élet szabadsága és a nemi erkölcs elleni büncselekményeket tartalmazó fejezet - mely a régi Btk. vonatkozó tényállásait, esetenként azokat jelentősen átalakítva tartalmazza - adatai ugyanakkor jelentősen nőttek az elmúlt két évtizedben. Ebben a változásban azonban szinte kizárólag a gyermekpornográfia játszott szerepet. E bűncselekmény ismertté vált adatai hektikusan alakultak a 2002. évben történt büncselekménnyé nyilvánítás óta. Az első években ugyanis száz körüli esetszám volt jellemző, amely később a többszörösére emelkedett, és a 2005. évben érte el maximumát (15 ezer esettel). Ezt követően ismét csak százas nagyságrendben kerültek be a statisztikába ilyen cselekmények, majd a 2013. évi adat újfent jelentős növekedést mutat. Ugyanakkor a 2014. évben rögzített adatok jelentős visszaesést jeleznek (5225-ről 142-re). A társadalmi érdeklődés és a közbiztonság szempontjából kiemelt jelentőségű szexuális erőszak büncselekmények száma a vizsgált két évtizedben harmadára csökkent. Az utóbbi években ötszáz körül, a 2014. évben pedig elöször négyszáz alatt alakult a regisztrált bűncselekményszám.

A regisztrált elkövetők száma 1994 óta 13\%-kal csökkent, ami - tekintve, hogy éves viszonylatban százezer föt meghaladó sokaságról beszélhetünk - jelentős mértékủ változásnak mondható. Nehéz megítélni, hogy kedvező vagy kedvezőtlen irányúként értelmezhető-e az a változás, amely az elkövetők elóélet szerinti adataiban 1994 óta eltelt évtizedekben megmutatkozik. A 2010. évtől ugyanis $26 \%$ volt a büntetett előéletüek részaránya, ezt megelőzően viszont a $36-37 \%$ volt a jellemző. A bemutatott arányok mögötti abszolút számok a teljes vizsgált időszak tekintetében igen nagy szórást mutatnak: volt olyan év, amikor 28 ezer elkövető minősült büntetett elóéletünek, és volt olyan év is, amikor ennek szinte pontosan a kétszerese. A büntetett elóéletủek között - a büntetéskiszabás szempontjából jelentőséggel bíró - visszaesői kategóriák valamelyikébe tartozók, éves szinten, $30-40 \%$-ot tesznek ki. ${ }^{4}$ Ezen belül is a visszaesők száma felére, a többszörös visszaesőké pedig kétötödére esett vissza, a különös visszaesők száma viszont lényegében változatlan maradt.

A bünelkövetők nemek szerinti megoszlása egyértelmüen a férfiak fölényét mutatja a kriminalitás területén. A nők részesedése 1994 óta - lassú, ám folyamatosnak mondható emelkedés eredményeként - 10-ről 16-17\%-ra nőtt (ezzel még mindig jóval elmaradva népességbeli arányuktól).

\footnotetext{
${ }^{4}$ Visszaeső a szándékos bủncselekmény elkövetője, ha korábban szándékos bűncselekmény elkövetése miatt végrehajtandó szabadságvesztésre ítélték, és az újabb bủncselekmény elkövetéséig három év még nem telt el; különös visszaeső az a visszaeső, aki mindkét alkalommal ugyanolyan vagy hasonló jellegű bűncselekményt követ el; többszörös visszaeső az, akit korábban visszaesőként végrehajtandó szabadságvesztésre ítéltek, és az újabb büncselekmény elkövetéséig 3 év még nem telt el; eröszakos többszörös visszaesö az, aki mindhárom alkalommal személy elleni erőszakos büncselekményt követ el.
} 
Az elmúlt húsz évben folyamatos növekedést mutat az elkövetők átlagéletkora. Az elkövetök szempontjából releváns - 12 és 90 év közötti - korcsoportot vizsgálva, 1995-ben egy átlagos elkövető 29 és fél éves volt, 2014-ben már több mint 34, míg a teljes társadalom 12-90 éves korcsoportjának átlagos életkora ez idő alatt alig több mint három évvel emelkedett. A teljes elkövetői szám 13,2\%-kal csökkent, ugyanezen mutató értéke 1994 és 2013 között a 14-17 évesek körében még markánsabb (29\%-os) változást jelez.

Más országok csökkenő bünözési adataiban is vannak „megingások”, az általános trend azonban ettől nem változik. Hozzá kell tehát fognunk azon feltételek és körülmények végiggondolásához, melyek mentén és hatására - szerte a világon - csökken a bünözés.

\section{A BÜNÖZÉS MÉRSÉKLŐDÉSÉNEK MAGYARÁZATA}

Három olyan változó van, amely minden kétséget kizáróan összekapcsolható a bünözés múltbeli alakulásával és jövőbeni változásaival: (1) a makrogazdasági tényezők (például: a gazdaság fejlettsége, a munkanélküliségi ráta, a fogyasztási jellemzők), (2) a demográfiai tényezők (különösen a nagyobb bünelkövetési gyakorisággal jellemezhető fiatal férfiak népességbeli megoszlása) és (3) a technológia, amely egyre meghatározóbb befolyást gyakorol a bünelkövetési lehetöségekre és módszerekre.

Az USA-ban már jobban körüljárták a bűnözés csökkenésének kérdéskörét, lévén a csökkenés hosszabb ideje tart, mint az európai országokban, és régebben is kezdődött. A figyelem mindenekelött az erőszakos bűnözés csökkenésének okaira irányul. Kiemelkedik a magyarázatok körül a „crack-járvány” lecsengése, ami a bandaháborúk befejeződéséhez vezetett. Ez utóbbi ugyanis szoros összefüggésben volt a kábítószer-terjesztéssel, a fegyvertartás szabályozásával, valamint a börtönnépesség létszámának emelkedésével (BlumsteinWallman, 2000). Gary LaFree (1998, 1367.) szerint a politikai intézményrendszerbe vetett bizalom erősödése, a jólét növekedése, és a családok támogatása áll a csökkenő bűnözési adatok mögött. Meghatározó, hogy miként tekintünk a csökkenésre: ciklikus vagy attól független változásként-e, és miként értékeljük a nagyvárosokban és a kisebb településeken bekövetkezett átalakulást. Az amerikai statisztikai adatok szerint a változás a nagyvárosokban kezdődött, és ezt a dinamikát vették át a kisebb települések. Fox Butterfield (1997) az USA-beli bünözés csökkenése és az ennek ellenére növekvő börtönnépesség összefüggéseit vizsgálva megállapította, hogy a börtönépítési boom a bűnözés csökkenése ellenére is érvényesül, mert a (magán)börtön-építés és -átalakítás financiálisan jól megtérülő befektetés. 
A kriminológusok számos magyarázó modellt és elméletet dolgoztak ki a bünözés létezésének magyarázatára, de a csökkenés magyarázata láthatóan nehézséget okoz. Paul Knepper szerint azért, mert a bünözés csökkenése túl sok elmélethez kapcsolódik, és hiányoznak a csökkenés vizsgálatára koncentráló empirikus kutatások is. Bár a 90-es évek bűnözési csökkenése meglepte a kriminológusokat, nem ez volt az első eset a bünözési trend megváltozására: az 1920-as években is hasonló apadást regisztráltak az Egyesült Királyságban, és az a bünözéscsökkenés, amelyet Anglia átélt az 1920-as években, nem különbözik attól, amelyet napjainkban tapasztalunk. Hiányzik viszont az értelmezéshez az az elméleti keret, amelybe az egyes magyarázatok beilleszthetők. Úgy tünik, hogy a büntető igazságszolgáltatás vizsgálata helyett a jelenleg egymással versengő gazdasági és a biztonságiasítási magyarázatokra kell figyelni. Kidolgozottabb elméleti modellekre van szükségünk abban a vonatkozásban is, hogy e két tényező hogyan hat a bünözésre. Ezért tehát előbb a problémát kell értelmezni, és nem az adatokat elemezni (Knepper, 2015).

Tagadhatatlan, hogy az európai magyarázatok is inkább támpontokat adnak, és nem koherens elméleti értelmezési keretet kínálnak. A holland szakemberek például azt hangsúlyozzák, hogy mivel a fiatalkori bünözés, illetve a visszaesés és a bűnismétlés megelőzését kiemelt feladatnak tekintette a holland kormányzat, az intézkedések eredményei is megjelentek a bünözési adatok mérséklödésében. Van Dijk a technikai fejlődésnek tulajdonítja a csökkenést, mert mind a háztartások, mind az üzleti szféra intenzíven alkalmazza a biztonsági eszközöket (van Dijk, 2008). A magyarázatok között szerepel az internet hatása, ami két ellentétes irányú jelenséget takar. A bünelkövetők egy része az internetes elfoglaltság miatt marad otthon, és nem követ el büncselekményt, azaz az internet közvetetten korlátozza a fiatalok bevonódását a bủnelkövetésbe, mert a korábbitól eltérő időtöltést kínál. Több időt töltenek otthon - a gép elött ülve -, nagyobb a számítógépes büncselekmények elkövetésének veszélye, de azok, akiknek nincs internetelérhetőségük továbbra is a bünelkövetővé válás nagyobb veszélyének vannak kitéve (Aebi-Linde, 2010). Lucia Zedner szerint általánosabb társadalmi átalakulás rejlik a bünözés változása mögött. Az a társadalom, amely a büncselekményre annak elkövetése után reagált, éppen napjainkban alakul át olyan társadalommá, amelyet a „számítás, a veszély és a bizonytalanság, a felügyelet, az elővigyázatosság, a gyanakvás, az erkölcsi kockázat, a megelőzés, és a biztonságra való törekvés jellemez" (Zedner, 2007), a biztonságiasítás erős hatást gyakorol a bünözés csökkenésére.

Az egyik legkevésbé vitatott kérdés napjaink rendészettudományi szakirodalmában a plurális rendőrség kialakulása, azaz megtört a közrendőrség rendészeti monopóliuma. Ebben az új helyzetben egyre több szolgáltató (úgy a közpolitikai feladatokat ellátók mint a piaci szereplők) egyre nagyobb mértékben vonódik be a bűnözés és a kisebb súlyú szabályszegések megelőzésébe és kezelésébe. Az 
elmúlt három évtizedben csendes forradalom zajlott le a közbiztonság, a bünözéskezelés és a büntető igazságszolgáltatás területén: a plurális rendőrség mára általánossá vált.

Finszter Géza megfogalmazásában a közbiztonság kooperációs termék, amelyben az állam hatósági szolgáltatásai és az önvédelem egyéni és kollektív teljesítményei összegződnek (Finszter, 2009, 170.). A hazai társadalom a közbiztonság megteremtését a rendőrségtől várja el, bár a lelke mélyén valószínúleg tudja, hogy erre a rendőrség egyedül nem képes. A hazai szcénán a rendőrség nincs is egyedül: kényszerítő eszközök és intézkedések alkalmazására jogosult meglehetősen nagyszámú további szereplő is megjelent az elmúlt két évtizedben.

\begin{tabular}{|c|c|c|c|}
\hline $\begin{array}{l}\text { Rendészeti } \\
\text { szervek }\end{array}$ & $\begin{array}{l}\text { Kényszerítő intézkedés alkalmazására } \\
\text { jogosított személy }\end{array}$ & $\begin{array}{l}\text { Magánbiztonsági } \\
\text { szereplő }\end{array}$ & $\begin{array}{c}\text { Civil } \\
\text { szereplő }\end{array}$ \\
\hline $\begin{array}{l}\text { - rendőrség } \\
\text { - Készenléti } \\
\text { Szolgálat } \\
\text { - TEK }\end{array}$ & $\begin{array}{l}\text { - természetvédelmi ör } \\
\text { - rendészeti feladatot ellátó erdészeti } \\
\text { szakszemélyzet } \\
\text { - erdővédelmi szolgálat tagja } \\
\text { - halászati őr } \\
\text { - hivatásos vadász } \\
\text { - hegyőr } \\
\text { - közterület-felügyelö } \\
\text { - önkormányzati természetvédelmi őr } \\
\text { - mezőőr } \\
\text { - javítóintézeti rendész }\end{array}$ & $\begin{array}{l}\text { - fegyveres } \\
\text { biztonsági őr } \\
\text { - személy- } \\
\text { és vagyonőr }\end{array}$ & - polgárőr \\
\hline
\end{tabular}

Okkal tehető fel a kérdés: van-e szerepe a hazai bünözési trend csökkenésében a rendészeti és kontrollfeladatokat ellátó személyek jelentős számú növekedésének.

A kérdés a nemzetközi szakirodalomban akként merült fel, hogy a rendőrség megváltozott szerepe, eltérő stílusú munkavégzése gyakorolhatott-e mérséklő hatást a bünözésre. Mint korábban részleteztem, a bünözés az 1990-es évek óta csökken az USA-ban, New Yorkban például az emberölési ráta nagyobbat zuhant, mint bárhol másutt az országban. A - különösen az állami szereplök által preferált - magyarázat szerint a csökkenés oka a New York-i rendőrség új stratégiája és taktikája, illetve az, hogy a büntető igazságszolgáltatás keményebben lépett fel a visszaeső bünözőkkel. A kutatási adatok azonban nem támasztják alá ezeket a feltételezéseket (Karmen, 2001, 12.). A szakirodalmi nézőpontok ütköztetése alapján hasonlóan vélekedik Michael Tonry is, kiemelve, hogy bármely magyarázatot is adtak a kutatók a bünözés rövid és hosszú távú csökkenésére, soha nem értékelték közvetlen hatásként a rendőrségi vagy

\footnotetext{
${ }^{5}$ Lásd továbbá az 59/2014. (XII. 8.) BM rendelet 5. számú mellékletét a javítóintézeti rendész rokonszakmáiról.
} 
a büntetéskiszabási gyakorlat megváltozását (Tonry, 2014). Hasonlóan, John E. Eck és Edward R. Maguire sem találtak meggyőző bizonyítékot arra, hogy a rendőrségi változások hozzájárultak volna a büncselekmények csökkenéséhez (Eck-Maguire, 2006). A hazai - különösen a rendészeti - szakirodalomban azonban nem elhanyagolható mértékben van jelen az a megközelítés, amely rendészeti intézkedéseknek és kormányzati lépéseknek tulajdonítja a csökkenést (Sallai et al., 2016).

\section{KÖVETKEZTETÉSEK}

A fentiekben három kérdés megválaszolására tettem kísérletet: 1. Csökken-e a bünözés Magyarországon? 2. Tapasztalhatók-e ilyen jelenségek más országokban is? 3. Mi a magyarázata a bünözés csökkenésének?

A ,bünügyi helyzet minden adat szerint kedvezően változott, és ez most már egy folyamatos trendnek tekinthető" - mondta a legföbb ügyész a 2017. évi parlamenti beszámolója szóbeli kiegészítéseként. A fejlett országok többségében jó ideje lehet látni a bűnözés csökkenését. A jelenség okán természetesen vitatkoznak a szakemberek, de a csökkenés annak ellenére igaz, hogy soha korábban nem lehetett ilyen könnyen egyéneket, vállalkozásokat és kormányzatokat katasztrofális következményekkel érintő cselekményeket elkövetni, adott esetben akár a világ másik végéről. Tény, hogy nincs általánosan elfogadott elméleti keret a csökkenő bünözéssel kapcsolatos tapasztalatok értelmezésére, de a szakirodalom sokféle módon interpretálta a helyzetet.

A háttértényezők közül ki kell emelni a gazdasági fellendülés és a munkanélküliség csökkenésének hatását, a demográfiai tényezőket, a bevándorlást és az olyan szakpolitikai tényezőket, mint a szabadságvesztési tartamok növekedése, illetve a szelektív semlegesítés ${ }^{6}$ általánossá válása. Jelentős szerepet játszik a csökkenés okai között a biztonsági eszközök elterjedése, amely mérsékelte a bünelkövetési lehetöségeket. Ha az elkövetési lehetőségek csökkennek, akkor kevesebben követik el a bünözői karrier kezdetét jelentő első büncselekményt. A bűnözés csökkenő trendjére meghatározó befolyást gyakoroltak a demográfiai változások, különösen a bünelkövető népesség kormegoszlását leginkább meghatározó a 15-25 éves korosztályban a fiatal férfiak számarányának csökkenése. A demográfiai változások másik oldala - az orvostudomány fejlődése és a technika előrehaladása miatt - az átlagéletkor kitolódása és az idősebb népesség életkori csoportjának jelentős számbeli növekedése. Az idősek lélekszáma elsősorban Európában növekszik: a 65 éven felüli európai népesség az elmúlt hatvan évben

\footnotetext{
${ }^{6}$ Az elv két formában valósul meg az igazságszolgáltatásban: a büntető törvénykönyv megnöveli a visszaesőkkel szemben alkalmazható szabadságvesztés időtartamát, vagy kötelező minimumbüntetés kiszabását rendeli el.
} 
megtriplázódott, a hatvan évesnél idősebbek száma pedig hatszor magasabb, mint 1950-ben volt. Az életkor elörehaladtával viszont egyre kevésbé valószínű a büncselekmény elkövetése. Speciálisan kelet-európai bünözéscsökkenési tényező a kivándorlás: a magyar népességből például hiányzik közel félmillió vétőképes korú, nyugaton munkát vállaló fiatal.

A fentiekben leírt új bünözési fejleményeknek jelentős szakpolitikai következményei vannak, vagy legalábbis ilyennek kellene lenniük. Hasznos és megbízható információk nélkül az országos és helyi politikai döntéshozók iránytű nélkül lehetnek a szakpolitikai beavatkozások megfogalmazása és értékelése során. Úgy tünik, hogy a kormányzati elképzelések és megoldások (lásd például a közfoglalkoztatás kialakításának közbiztonsági és bünmegelőzési indokait) alapvetően egy stagnáló vagy inkább növekvő hazai bűnözés képén alapulnak. Az elmúlt két évtized kriminálpolitikai szigorításai rendre ebbe az irányba haladtak, azt hívén, hogy a bűnözés visszaszorítása a rendőrségi és a kontrolleszközök alkalmazásával érhető el. Jelen összegzés azt javasolja, hogy gondoljuk végig ezt a feltételezést. Részben abból a szempontból, hogy hol, milyen mértékben és a bünözés mely formáival kapcsolatosan változtak meg a trendek. Az áttekintés azt is igazolja, hogy a biztonsági technika valóban segíti a bünözés csökkentését: kormányzati felelősség tehát a bűnözéstől védett eszközök kialakítása (biztonságos otthonok, a számítógépek, gépkocsik, telefonok beépített biztonsági eszközei stb.), és az építészeti és szociális bünmegelőzési eszközöknek és módszereknek itthon is nagyobb szerepet kell kapniuk, mint eddig.

Összegzésként azonban le kell szögeznünk, hogy a hazai tömegkriminalitásban továbbra sincs olyan fenyegető új hatás, amelynek a társadalom aggodalmát fel kellene keltenie. A regisztrált büncselekmények további csökkenése várható, és nem változik az a helyzet sem, hogy az interperszonális cselekmények (az erőszakos és a vagyon elleni bünözés) határozzák meg az ismertté vált bünözés alakulását. Feltehetően nem változik az a helyzet sem, hogy a csökkenő mértékü bünözés ellenére egyre nagyobb költségekkel jár a büntető igazságszolgáltatás működtetése. Erre a jelenségre már utaltam azzal, hogy a bünözés csökkenését nem követte a börtönnépesség létszámának apadása az Egyesült Államokban. A hazai költségvetésben is egyre nagyobb ráfordításokkal működik az igazságszolgáltatás rendszere, határozottan aláhúzva annak a megállapításnak a helytállóságát, hogy a bünözés csökkenése nem az igazságszolgáltatási beavatkozások következménye.

\section{IRODALOM}

Aebi, M. F. - Linde, A. (2010): Is There a Crime Drop in Western Europe? European Journal on Criminal Policy and Research, 16, 4, 251-277. DOI: 10.1007/s10610-010-9130-y, https://www. researchgate.net/publication/227193492_Is_There_a_Crime_Drop_in_Western_Europe 
Blumstein, A. - Wallman, J. (eds.) (2000): The Crime Drop in America. New York: Cambridge University Press, http://www.cambridge.org/us/academic/subjects/sociology/criminology/crime-drop-america-2nd-edition

Butterfield, F. (1997): Punitive Damages; Crime Keeps on Falling, But Prisons Keep on Filling. New York Times, 28 Sept. 1997. 147, 50929, Section 4, p1. 0p. 2, https://www.nytimes. com/1997/09/28/weekinreview/punitive-damages-crime-keeps-on-falling-but-prisons-keep-on-filling.html

de Waard, J. (2015): The Crime Drop in The Netherlands and Other Industrialized Countries: Trends and Possible Explanations. Working Paper, The Hague: Dutch Ministry of Security and Justice, Directorate for Law Enforcement and Crime Control, 0105 2015. DOI: 10.13140/ RG.2.1.2526.9841, https:/www.researchgate.net/publication/287759866_The_crime_drop_in_ The_Netherlands_and_other_industrialized_countries_Trends_and_possible_explanations

Eck, J. E. - Maguire, E. R. (2006): Have Changes in Policing Reduced Violent Crime? : An assessment of the evidence. In: A. Blumstein - J. Wallman (eds.): The Crime Drop in America. New York, NY: Cambridge University Press, 207-265. DOI: 10.1017/CBO9780511616167.008, https://www.researchgate.net/publication/285942862_Have_changes_in_policing_reduced_violent_crime_An_assessment_of_the_evidence

Finszter G. (2009): Közbiztonság és jogállam. Jog - Állam - Politika. Deák Ferenc Állam- és Jogtudományi Kar, Győr, https://dfk-online.sze.hu/images/J\%C3\%81P/2009/3/Finszter.pdf

Irk F. (szerk.) (2004): Áldozatok és vélemények I-II. Budapest: Országos Kriminológiai Intézet

Kaiser, T. (szerk.) (2015): Jó Állam Jelentés, 2015. Budapest: Nemzeti Közszolgálati Egyetem-Dialóg Campus Kiadó, https://joallamjelentes.uni-nke.hu/kiadvanyok/jo-allamjelentes-2015/

Karmen, A. (2001): Smarter Policing and Stepped-up Imprisonment as the Primary Causes of Falling Crime Rates in New York City: The Emergence of an Urban Legend? Justice Policy Journal, 1, 1, 60-71. https://www.ncjrs.gov/App/Publications/abstract.aspx?ID=199587

Kerezsi K. - Pap A. L. (2017): A bünözés és a bünözéskontroll jövője. In: Finszter G. - Sabjanics I. (szerk.): Biztonsági kihívások a 21. században. Budapest: Dialóg Campus Kiadó, 543-584.

Kesteren, J. N. - Van Dijk, J. - Mayhew, P. (2013): The International Crime Victims Surveys: A Retrospective. International Review of Victimology, 20, 1, 49-69. DOI: 10.1177/0269758013511742, https://pure.uvt.nl/ws/portalfiles/portal/1578919/ICVSretrospective2013.pdf

Knepper, P. (2015): Falling Crime Rates: What Happened Last Time. Theoretical Criminology, 19, 1, 59-76. DOI: 10.1177/1362480614541290, https://www.researchgate.net/publication/272395804_Falling_crime_rates_What_happened_last_time

LaFree, G. (1998): Social Institutions and the Crime Bust of the 1990s. Journal of Criminal Law and Criminology, 88, 1325-1368. https://scholarlycommons.law.northwestern.edu/jclc/vol88/ iss $4 / 6 /$

Martinez, R. - Iwama, J. A. - Stowell, J. I. (2015): Race, Immigration, and Homicide in Contemporary Europe and the United States: An Urban Comparison. C.L. \& S.C., 64, 4-5, 291-304. DOI: 10.1007/s10611-015-9591-5, https:/www.researchgate.net/publication/283430554_Race_ immigration_and_homicide_in_contemporary_Europe_and_the_United_States_an_urban_ comparison

Papachristos, A. V. - Brazil, N. - Cheng, T. (2018): Understanding the Crime Gap: Violence and Inequality in an American City. City \& Community, October, American Sociological Association, DOI: 10.1111/cico.12348, https://www.researchgate.net/publication/329368135_Understanding_the_Crime_Gap_Violence_and_Inequality_in_an_American_City_UNDERSTANDING_THE_CRIME_GAP

Pusztai L. (1987): Gazdasági ciklus és bünözés. Belügyi Szemle, 9, 34-42. 
Sallai J. - Tihanyi M. - Vári V. - Mátyás Sz. (2016): A ,jó rendészet” közpolitikai kapcsolódási lehetőségei. Államtudományi Műhelytanulmányok, 2016. évi 31. sz. https://folyoiratok.uni-nke. hu/document/uni-nke-hu/2016_-evi-31_-szam-a-__jo-rendeszet-kozpolitikai-kapcsolodasi-lehetosegei.original.pdf

Shaw, M. - van Dijk, J. - Rhomberg, W.: Determining Trends in Global Crime and Justice: An Overview of Results. Forum on Crime and Society, 3, 1-2. December 2003, 41.

Tcherni-Buzzeo, M. (2018): The "Great American Crime Decline": Possible Explanations. In: Krohn, M. D. - Hendrix, N. - Hall, G. P. et al. (eds.): Handbook on Crime and Deviance. (Handbooks of Sociology and Social Research) 309-335. DOI: 10.13140/RG.2.2.11063.21921, https://www.researchgate.net/publication/326020920_The_Great_American_Crime_Decline_Possible_Explanations

Tonry, M. (2014): Why Crime Rates Are Falling throughout the Western World. Crime and Justice, 43, 1, 1-63. https://scholarship.law.umn.edu/cgi/viewcontent.cgi?article=1521\&context= faculty_articles

Van Dijk, J. J. M. (2008): The World of Crime. London: Sage, 129-130.

Zedner, L. (2007): Pre-crime and Post-criminology? Theoretical Criminology, 11, 2, 261-281. DOI: 10.1177/1362480607075851, https://openresearch-repository.anu.edu.au/handle/1885/30092 